\title{
The Resistance of Architecture to Political Regime(s): the Case of Novi Zagreb
}

\author{
Dubravka Vranić \\ FORMA studio, d.o.o., Zagreb, Croatia \\ e-mail:dubravkavranic@gmail.com
}

\begin{abstract}
This paper draws upon the case study of Novi Zagreb to examine the extent to which architecture can resist political authority. Although the circumstances of its conception are still obscure, I argue that it came into existence as an outcome of the resistance of architecture to political forces. In contrast to the existing studies claiming that the first urban complexes of the Naval Institute and Zagreb Fair, were built on the south side of the river Sava without the intention to build the housing, my hypothesis is that their construction was part of the project to build a modernist city from the very beginning, long before the first Plan for South Zagreb in 1962. The archival research and in-depth interviews show that the majority of strategic decisions about the infrastructural projects, which enabled the construction of the modernist city a decade later, were made in the late 1940s and the early 1950s. At the same time, in the late 1940s, Croatian architects, by resisting the imposition of Social Realist aesthetic doctrines, defined the modernist paradigm of the "functional city" as a model for the construction of the new socialist reality. After the political control over the arts diminished in the early 1950s, the local authorities immediately applied the idea of a modernist city through thoughtful infrastructure planning. Thus, the actions of the architects resisting the political pressures of the state may be considered to be architecture's capacity to develop autonomously, when restricted by authoritarian powers, which, in the case of Novi Zagreb, led to the creation of an alternative city offering excellent living conditions today.
\end{abstract}

Key words: Novi Zagreb, modernist city, functional city, architectural autonomy, resistance of architecture.

\section{Introduction: The Relationship between Architecture and Society}

The circumstances of Novi Zagreb's inception are still obscure, which is why some authors describe this major city area, built along modernist lines south of the river Sava after the World War Two (WWII), as a "group of spatially independent neighborhoods" and do not see it as a coherent whole (Fisher, 1985; Gulin Zrnić, 2009). However, on the basis of archival research and interviews with the participants, this study argues that it was a planned project from its very beginnings, long before the 
first Plan for South Zagreb ${ }^{1}$ (1962). The fact is that the Plan for South Zagreb (1962) appeared 15 years after the competition of New Belgrade's state and party buildings (1947). It came almost a decade after the construction of the first urban complexes, the Naval Institute (1949-1959) and Zagreb Fair (1954-1956), and a few years lagging behind the first entirely planned neighborhood Micro-rayon Novi Zagreb² (1959). The archival research shows that the decisions about the construction of those first infrastructural ${ }^{3}$ projects were made in the late 1940 s and early 1950s. At the same time, in the late 1940s, the regime had strong control over artistic production, and Socialist Realism was imposed upon architecture as the official poetics. In contrast to the studies that claim that the Naval Institute and Zagreb Fair were built without intention to build housing (Fisher, 1985; Gulin Zrnić, 2009), this study argues that the construction of those first urban projects across the river was part of a thoughtfully engineered strategy to circumvent the totalitarian regime and build a modernist city. The hypothesis is that Novi Zagreb was conceived as an act of resistance of the Croatian architects toward the regime's pressures, which makes it a suitable case study for exploring to what extent and under which circumstances architecture is able to resist political authority.

To unravel the obscurities about its inception, I examine the relationship between architecture $^{4}$ and society, of which the city is the most immediate reflection. On one hand there is a position that perceives architecture as an instrument of culture dependent on external realities such as socioeconomic, political and technological

" I would like to thank Bojan Bilić, Linda M. Bleijenberg, Dragutin Novosel, Andrej Radman, Aleksandar Štulhofer and the anonymous reviewers for their constructive criticisms, suggestions and support. I am particularly grateful to my interviewees, architects who directly or indirectly took part in the construction of Novi Zagreb: Bogdan Budimirov, Branko Kincl, Neven Kovačević, Professor Boris Magaš, Nada and Josip Uhlik, as well as Professor Krešimir Ivaniš who put me in touch with them.

* The shortened version of this paper will be presented at the Third International Meeting of European Architectural History Network (EAHN) in Turin, Italy, from 19 to 21 June, 2014.

1 HR-GUSPRG-technical documentation-0.10-5.1-urban program-, Urbanization of Novi Zagreb; "Plan for South Zagreb" was made by Urbanistički zavod grada Zagreba (Zagreb's Urban Planning Department) and a group of architects: Neda Bešlić, Vojteh Delfin, Vladimir Ivanović, Grozdan Knežević, Zdenko Kolacio, Mirko Maretić, Zdenka Smolej i Josip Uhlik and other professionals, 1962.

2 HR-GUSPRG-technical documentation-0.10.16-5.1, -Micro-rayon Novi Zagreb, Zagreb's Urban Planning Department, 1959. Today, Micro-rayon Novi Zagreb is called Trnsko.

3 By infrastructure, I refer to technical structure that supports society, both as technical infrastructure (such as roads, bridges, watter supply, sewers, electrical grids, telecommunications, heating plants) and social infrastructure and amenities (such as schools, recreational areas, swimming pools, and services). In this respect, I refer to the Naval Institute and Zagreb Fair as infrastructural projects because they set up the framework for the future city.

${ }^{4}$ In this paper architecture is understood in a broader sense as an activity giving form to space, giving meaning to the environment (Eisenman, 2006); therefore, there is no particular distinction between city planning and architecture as an art of building. 
forces, while for the other architecture is as autonomous form capable of resisting external influences (Hays, 1984:16). This second position relies on the concept of architectural autonomy which opens up the possibility for architecture to address social issues responsibly and be other than a mere servant to ideological, commercial or capitalist forces. While cities usually come into being as a reflection of social and political circumstances, (like, for example, Brasília5), I take into account the complexity of socio-political circumstances in post-WWII Croatia and claim that Novi Zagreb was conceived as a project aiming to change those circumstances (Rogić, 2003). In this regard, my argument is more in line with the second of the abovementioned positions, which understands architecture as autonomous form.

In the first section of this paper, I explore the concept of architectural autonomy to determine in which way and to what extent architecture can resist social and political influences. The second part describes incongruity between the existing studies and my findings about the conception of Novi Zagreb. Finally, a recent theory about architectural autonomy, which shows that architecture indeed is capable of resisting external influences during the times of social upheavals (Kaminer, 2011) is applied to the case of Novi Zagreb, to find out whether it was conceived autonomously from political influences.

\section{Architectural Autonomy}

Architecture is, in essence, giving form to space (Eisenman, 2006:33). To fully comprehend what is meant by the resistance of architecture, it is necessary to understand the concept of the autonomy ${ }^{6}$ of form, because only an autonomous system, which has defined its rules and constituted its capacities and limits, is capable of resisting external forces. The origins of the concept of autonomy of form can be found in the shift from the ancient to modern concept of form. While in the ancient concept of form the responsibility for the form-giving process is assigned to the divine, in the modern concept of form, it has shifted from the divine to a human mind. The main reason for this change lies in the Copernican reversal of Immanuel Kant's thinking, which presupposes the active participation of the human mind in a cognitive process, in which the observer (subject), through his/her pure forms of intuition and forms of thought, regulates conceptual structuring of the world (ob-

5 Brasília is usually seen as a paradigmatic case of a planned modernist city, showing the scope and breadth of influence that society and politics had on its conception. The idea of developing the country by moving the capital city into the interior was conceived as early as 1789. During the centuries, the idea was constantly linked with democratic hope and it reappeared in the public debate after the dictatorship was defeated. Once Juscelino Kubitschek, who promised "fifty years of prosperity in five", decided to build it, the competition was held, and the city was constructed in only four years, from 1956-1960. Lúcio Costa's Plano Piloto became the materialization of Brazilian society's positivist belief in Ordem e Progresso (Jong and Mattie, 1994:41).

$\mathbf{6}$ The word autonomy comes from the Greek auto (self) and -nomos (law) which means to give to oneself one's own laws. 
ject) (Mallgrave and Ikonomou, 1994). Therefore, the modern concept of form does not rely so much on the representation of the world, as much as on theorizing the relationship between subject and object. By positing a human being in the center of the cognitive process, the artistic activity has consequently become autonomous: independent from political, social and religious processes that have previously constituted it (Aureli, 2009).

Ever since the concept of autonomy has emerged in the world of the arts, it has radically changed its understanding and the course of its development. While its introduction into fine arts meant the disengagement from statecraft and religion breaking its connections with society, its emergence in architecture, which remained dependent on authority and power, has profoundly changed it. Since the Renaissance invention of perspective, drawing and geometry became its main constituting elements. Architecture is no longer a building, or a material object itself, but becomes an ideal object, a product of the mind. It ceases to be a craft, and instead becomes a discipline. As a discipline, it becomes a sort of intangible institution "constituted by the accumulative effect of real institutions, organizations and products" (Kaminer, 2011:4), and as such, has different mechanisms of exercising power in comparison to real institutions. In contrast to an enclosed institution, a discipline exercises power "by making it lighter, more rapid, more effective, a design of subtle coercion for a society to come" (Foucault, 1977:209). According to Foucault, the discipline is, in its mechanism, "counter-law." It seems to extend the general rules defined by law to another level of individual lives, because it is based on the "private" link between individuals, "a relation of constraints entirely different from contractual obligation" (Foucault, 1977:222).

Although the universal juridicism of modern society seems to fix limits on the exercise of power, its [discipline's] universally widespread panopticism enables it to operate, on the underside of the law, a machinery that is both immense and minute, which supports, reinforces, multiplies the asymmetry of power and undermine the limits that are traced around the law. The minute disciplines, the panopticisms of every day may well be below the level of emergence of the great apparatuses and the great political struggles. But, in the genealogy of modern society, they have been, [...], the political counterpart of the juridical norms according to which power was redistributed. (Foucault, 1977:223)

As a discipline, architecture "possesses a certain consciousness, a specific understanding and a worldview" (Kaminer, 2011:4) that is related more to the knowledge of the architect and the process of thought. This enables it withdrawal into itself and an internal investigation and resuscitation in the realm of the "ideal." The "ideal" refers to everything that prioritizes "consciousness over matter" in contrast to the "real" which is obsessed "with the concrete matter" (Kaminer, 2011:5), just as Plato's world of ideas is opposed to the material world. This duality of ideal-real that corresponds to the subject-object dichotomy arises from the idealist roots of architecture, and is responsible for architectural autonomy, the capacity of the internal exploration of its own specific language (Vidler, 2002:16). 
With the emergence of the concept of autonomy in architecture ${ }^{7}$, the relationship between society and architecture became more complex and ambivalent. According to Hays (Hays, 1984:16), the multitude of theories about their reciprocal influences have crystallized around the two opposing positions; the first position perceives architecture as an epiphenomenon of culture dependent on external realities such as socioeconomic, political and technological processes, while for the opposite position architecture is an autonomous form relying on its inherent properties that are disengaged from the historical contingency ${ }^{8}$ and, as such, capable of resisting external influences. The question is not whether architecture and society influence each other but what is the extent of their reciprocal influences? Hays positions architecture between culture and form, affirming that architecture is an autonomous discipline, at the same time being determined by social circumstances. This quasi-autonomous ${ }^{9}$ position is further explored in a recent study (Kaminer, 2011) that analyses how architecture is affected by social transformations and how it can resist them. Kaminer shows that the discipline of architecture during the times of social crisis cyclically passes the route of recovery by withdrawing into the realm of "ideal" in order to be able to engage itself again within the realm of the "real". He argues that:

A disciplinary reaction to situations of crisis and social transformation: a withdrawal into itself as escapism or resistance and resuscitation in "seclusion," followed by a "return," which expresses the acceptance of the new social order and a mastering of new techniques and understandings as a means of relating to the changed socio-economic landscape. The withdrawal is into the realm of ideal, a realm secluded from everyday life and from contamination by the unacceptable new order (Kaminer, 2011:5).

\footnotetext{
7 The one to introduce the concept of autonomy in architecture was Viennese architecture historian, Emil Kaufman, who connected Kant's philosophical position of "autonomy of will" with architecture. Analyzing works of Claude-Nicolas Ledoux, he discerned the emergence of the composition of autonomous entities in contrast to the Baroque principle of concatenation. In his 1933 pamphlet Von Ledoux bis Le Corbusier, Ursprung und Entwicklung der Autonomen Architectur (Kaufman, 1985[1933]), he proposed that the development of modernism emerged in the work of Claude-Nicolas Ledoux in the 1770s and culminated in the work of Le Corbusier in the late 1920s. It was Kaufman who introduced the ideas of autonomy and modernism to subsequent generations of architects, starting with Philip Johnson in the 1940s, followed by Colin Rowe in the 1950s and Aldo Rossi in the 1950s and 1960s, and continuing with Peter Eisenman and M.K. Hays from the 1970s up to today (Vidler, 2002:16).
}

$\mathbf{8}$ Hays describes these two positions as architecture as an instrument of culture and architecture as an autonomous form. The first view sees "culture as the cause and content of the built form". The opposite position considers the autonomy of an abstract formal system exempt from pre-existing cultural values as the main constituting factor of architectural form. In this view, architectural objects are containers of the principle of internal coherence, disengaged from the historical contingency and circumstances. (Hays, 1984:16)

9 Stanford Anderson prefers using the term "quasi-autonomy" over "semi-autonomy" for architecture's position between an autonomous discipline and cultural product (Anderson, 2002:30). 
He asserts that "the act of resistance by withdrawal" is a necessary stage in the process of adjustment "en route to establishing the methodologies, techniques and procedures that would accommodate the emerging new social order" (Kaminer, 2011:169). According to his thesis, the resistance of architecture is its capacity to go counter the existing social and political forces by withdrawing into the realm of the ideal, resuscitating itself, and becoming able to eventually return to reality ready to face the logic and the worldview of the new society.

In line with his thesis that during the times of social upheaval the discipline of architecture is capable of transforming itself autonomously for facing a new social order, I claim that Novi Zagreb was an autonomous project. As cities are centers of political power, I focus on the relationship between architecture and politics. Before testing the reciprocal influences of architecture and politics in Zagreb, and their consequences on Novi Zagreb's conception, I review the existing studies and present my archival findings regarding the development of this part of Croatia's capital city.

\section{Novi Zagreb - a Group of Fortuitously Connected Neighborhoods?}

Novi Zagreb is a part of Zagreb built after WWII to accommodate a new class of workers in the new socialist society. Originally conceived as a city for 250,000 inhabitants (Kolacio, 1962) (Figure 1), today it is a home to around 120,000 residents (Gulin Zrnić, 2009:85) because it has never been completely finished. Although it was criticized for years by both sociologists and architects (Gulin Zrnić, 2009:54-61), as well as perceived as a failure of modern urbanism (Blake, 1977:85-86), it has eventually became a convenient place to live, as shown by a recent anthropological study (Gulin Zrnić, 2009). I argue that the existing quality of living did not happen as a fortuitous accident, but instead came about as an outcome of an architectural project. Claiming that Novi Zagreb was a project does not necessarily mean that there was a drawing or a design upon which something was built. It means that there was a strategy by which something came into existence. The project here is understood along the lines of what Aureli called "autonomy of the project," meaning that there is "the possibility for architectural thought to propose an alternative idea of the city rather than simply confirming its existing conditions" (Aureli, 2011:XIII).

There is a lack of literature on the urban development of Novi Zagreb. This shortage might be the result of Zagreb's complicated socio-political position within Yugoslavia in the post-war period (Banac, 1988). In the available literature there are few studies that deal with the urban development of Novi Zagreb (Fisher, 1985; Blau and Rupnik, 2007; Gulin Zrnić, 2009; Bobovec, Mlinar and Sentić, 2012) and several about the modernism or the post-WWII architecture and urbanism of Zagreb, which usually either do not mention Novi Zagreb, implicating it is not considered to be a modernist city (Domljan, 1969; Franković, 1985; Premerl, 2003; Križić Roban, 2012), or do not mention it in a sufficient manner (Radović Mahečić, 2003). Although most studies agree that its neighborhoods were planned along the modernist lines (Radović Mahečić, 2003:82; Blau and Rupnik, 2007:246; Gulin Zrnić, 2009:61), none of them states clearly how, why and when exactly Novi Zagreb was conceived or the reasoning behind its planning. 
Figure 1

Plan for South Zagreb; Urbanistički zavod grada Zagreba; 1962 (Kolacio, 1962)

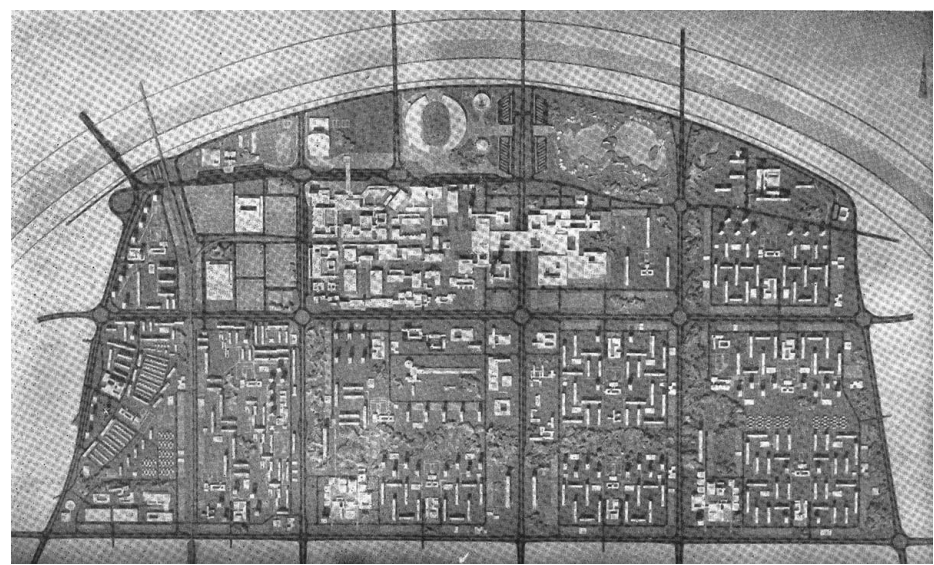

Source: Kolacio, 1962:4

Although the primary focus of the anthropological study Kvartovska Spika (Gulin Zrnić, 2009) is the quality of living in Novi Zagreb's neighborhoods, the chapter about Novi Zagreb's urban development provides up to date the most comprehensive overview of its construction. Based on a thorough archival research, it presents a socio-political context of its development by analyzing Zagreb's urban plans, ideological values of socialist society and urban sociology studies. Drawing upon the Athens Charter (Marinović-Uzelac, 1984), the author explains in detail why "Novi Zagreb is, by its urban concept and architectural resolution, the city of modern architecture and functionalist urban planning" (Gulin Zrnić, 2009:61) thus arguing it was one meaningful project based on the idea of "functional city." However, describing its chronological development, the author cites Fisher (1985:88) and somewhat contradictorily claims that "Novi Zagreb consists of a group of 'spatially independent settlements' which together do not form a coherent whole" (Gulin Zrnić, 2009:44). This position is similarly held by Radovič Mahečić who asserts that this new part of the city "is built primarily as a cluster of separately-planned residential complexes” (Radović Mahečić, 2003:82). Examining Novi Zagreb’s conception further, Gulin Zrnić claims that during the construction of the Naval Institute and Zagreb Fair in the mid 1950s, there was neither the idea of a mass housing construction nor the urban plan of Novi Zagreb as a coherent project (Gulin Zrnić, 2009:69), again referring to Fischer's paper. In that paper, Fischer states that there was no intention of building the housing across the river Sava, let alone a mass housing construction, by the time the first urban complexes had been built which is confirmed by their character (Fisher, 1985:88).

In contrast to Fisher and Gulin Zrnić, this paper argues that even though there was no urban plan for Novi Zagreb in the mid-1950s, there was a strategy for creating a modern city based on the modernist paradigm of the "functional city" which used mass housing techniques for satisfying then pressing needs for housing in Zagreb 
that "required radical solutions."10 It argues that the construction of the Naval Institute and the relocation of Zagreb Fair were part of the strategy that prepared the framework for the future construction of the modernist city. Assuming that these first infrastructural works were part of one project, implies that the inception of Novi Zagreb had begun earlier, in the late 1940s and the early 1950s, which is why I focus my archival research on the political decisions from the earlier period. The ongoing study of oral history interviews with the architects, who took part in the planning and decision making process, gave vital direction to the archival research and provided a more insightful account of the conception of Novi Zagreb.

A review of architectural periodicals ${ }^{11}$ revealed further incongruities in the facts about Novi Zagreb's inception. South Zagreb was first mentioned as a city in 1960, in the Croatian magazine Crovjek i Prostor. On the occasion of publishing issue 100 of this magazine, the mayor, Većeslav Holjevac, stated that "the beginning of intensive housing construction, which started three years ago on the other side of the river Sava, in fact, marks the formation of the new city for 250,000 inhabitants" (Holjevac, 1960:1). Although the first announcement of the city's expansion to the south had appeared in the same journal two years earlier (Petrović, 1958:2), the Plan for South Zagreb (Kolacio, 1962:4-6), with a detailed explanation of the city's organization, was published only two years after the mayor's first proclamation, and appears to have been only a justification of what was already going on: the entire city was under construction.

$\mathbf{1 0}$ The lack of housing was one of the most acute problems in postwar Zagreb. After WWII, the population grew at a rapid pace (from 258,024 in 1931 to 478,076 in 1962), a trend that started with industrialization after WWI, when the population doubled in the between-war period (from 136,351 in 1910 to 258,024 in 1931). The gravity of the housing problem can be traced in both magazines, Covjek i Prostor and Arbitektura, as well as in the Records of the City Committee of the City of Zagreb from 1952-1957. On the cover page of the first issue of Covjek i prostor (1954), there was a title, "The Right to an Apartment" while in the same magazine in 1957, an article titled "Housing Situtation in Zagreb seeks Radical Solutions" (Despot, 1957) suggested that 30,000 housing units were needed in Zagreb to accomodate existing needs, plus 4,000 for each coming year because the population was growing by 15,000 inhabitants every year. In 1956, Arbitektura was devoted to the housing problem and the report from the first Yugoslav conference on housing in the cities concluded that there was indeed a huge shortage in housing ("Zaključci prvog jugosl. savjetovanja o stambenoj izgradnji i stanovanju u gradovima," 1956). Šegvić wrote a text on the topic of 51,576 aparments a year (Šegvić, 1956) that were missing. Housing as a main problem in Zagreb was discussed on the 22st city assembly NOGZ, 25.1.1954. President's Annual Report about the work of NOGZ in 1953. 19.01.1954. p.44/29.HR DAZG-37-NOGZ-1954/I, sig. 38.

11 For the purposes of this article, the journals Čovjek $i$ Prostor (Man and Space) (from the first issue in 1954 to 1965) and Arhitektura (Architecture) (from the first issue in 1947 to 1965) were reviewed. 
According to the recollections of Josip Uhlik, ${ }^{12}$ an architect who actively took part in the planning of South Zagreb, after the war "there was strong industrialization in Zagreb. The workers were coming from all over Yugoslavia and there was a pressing need to build housing. Hence, the local authorities were in search for the space where an organized construction could take place in accordance with the technological capabilities. [...] They were in search for the free areas where nothing needed to be removed and demolished, and it was them, of course, who took the decision to cross the river and build south of Sava."13

The idea of expansion to the south has been continuously present in Zagreb's urban history. Zagreb developed on the southern slopes of the Medvednica mountain, far from the alluvial river in the south, and the land which was marshy, foggy and wet. Regardless of the natural disadvantages and the constant threat of flooding, the idea of the expansion to the south across the river came up whenever the city needed to develop further. Lenuci's Regulation Plan from 1907 to 1910 (Jukić, 1997:117-119) was the first to propose the city's development across the river. The idea was further explored in the open international competition for a new regulation plan for Zagreb, which was held in 1930/31. The new regulation plan intended to increase the urban territory of Zagreb including Trnje, the area between the railway and the Sava river, but several entries went further south suggesting its development across the river. ${ }^{14}$ The results of the competition served Antolic and the City Regulation Office as a basis for the development of the 1936 and 1947 Regulation plans for Zagreb, which announced the possibility of expansion to the south, and served as effective plans for the construction of the city although neither of them was ever officially accepted.

Josip Uhlik further recalls that "even though there were many disagreements and critiques among professionals regarding the crossing of the river [...] it is interesting that all professionals, including engineers, civil engineers and art historians, were vigorously engaged, and at the same time divided about how the city should develop." He remembers that in 1958 "it was already roughly clear that the city was expanding in south Zagreb. The idea was clear, but the exact layout of the neighborhoods was not yet known." That the architectural milieu in Zagreb was acquainted with the fact that the new city was envisioned on the south side of the river Sava testifies the program for the School Building Center (Građevinski školski centar -

12 Josip Uhlik (1921- ) was one of the most important architects of South Zagreb. He was the right hand man of Zdenko Kolacio, a manager of Zagreb's Urban Planning Department which was in charge of the planning of Novi Zagreb. He designed Zagreb's airport, Micro-rayon Novi Zagreb, Zapruđe, and was the author of Zagreb's 1972 masterplan.

13 An interview with Josip and Nada Uhlik conducted on 5 February 2013.

${ }^{14}$ Some entries proposed the expansion across the river, such as the 2nd prize winner, titled "Jelačić" by Erich Koetzer, Ewald Liedecke, Peter Koller, and the IVth prize titled "Grad Hrvata" by Carl Christof Lörcher, consultant: Werner Fabrucci (Laslo, 1984). 
GŠC) in South Zagreb dating from 1956, where there is a description of south Zagreb as a new city for 200,000 inhabitants across the river. ${ }^{15}$

However, Uhlik says, "Fair was probably Holjevac's decisive stroke 'Let's go over the Sava River." He remembers that it was absolutely clear that the relocation of the Fair would open the possibility for the city's construction. ${ }^{16}$ There are also several studies that claim that the relocation of Zagreb Fair was the generator of urban development of Novi Zagreb. In Project Zagreb, Blau and Rupnik claim that "the Zagreb fair enabled the city to embark on the planning and construction of Novi Zagreb" and that "the mayor piggy-backed Novi Zagreb onto the Fair, building housing districts around the fairgrounds" (Blau and Rupnik, 2007: 246). They further assert that "the relocation of the International Fair to the south side of the Sava has opened a new terrain for the development and expansion of the city." Similarly, the authors of the recent article on Zagreb's Fair (Bobovec et al., 2012) focus on its role as an urban generator of Novi Zagreb's development.

According to the archival findings ${ }^{17}$ the first urban complex that was built on the south side of the river Sava was the Naval Institute (Figure 2). It was founded by Marshal Tito in 1948, for the purposes of the Yugoslav Navy, just a few months after the radical break with Stalin. ${ }^{18}$ Already, in 1949, it was decided that it would be located south of the river Sava because of its urban potential and the "suitability of the gravelly soil" due to the technical requirements. ${ }^{19}$ The construction started in the late $1950 \mathrm{~s},{ }^{20}$ and the majority of the buildings were built by $1953 .{ }^{21}$ Prior to its construction, the exten-

15

HR-DAZG-1122-ZGD, AVENIJA V.HOLJEVCA; GŠC1956.-1958. sig.115; School Building center South Zagreb, The site description is not dated, but it is included with the approvals for the location of the school center from 1956.

16 The other interviewees Bogdan Budimirov, Boris Magaš and Branko Kincl confirm this.

17 I investigated HR-DAZG-37-NOGZ-Zapisnici sjednica gradskog vijeća NOGZ-Narodni odbor grada Zagreba (The records of the meetings of NOGZ-National Committee of the City of Zagreb) from 1952-1957 and HR-DAZG-1122-ZGD (Zbirka građevinske dokumentacijeCollection of building documentation), the Naval Institute archive (BI) which was not open until the mid-1990s because it was a military institution, GUSPRG, and the MGZ photo archive and HDA photo collection.

18 HR-BI-directive about the foundation of the Naval Scientific Institute, Belgrade, Josip Broz Tito 18.6.1948.

19 HR-BI-records of the meeting held on the premises of the Institute of Engineering (Inženjerski projektni zavod) on 4.11.1949. Vladimir Antolić, Kruno Tonković and Marijan Haberle were present at the meeting.

20 HR-BI-the approval of the location for the Naval Institue, pov.br. 20/53, 23.5.1953, where it is written that the first approval for the location of the Naval Institute was issued pov.br. 109, 30.5.1950. Approval for the road to the Institute 1125-IX-1951, 6.2.1951.

$\mathbf{2 1}$ HR-BI-the letter from the Naval Institute's manager, Stanko Šilović, to mayor Većeslav Holjevac, 8.8.1953. 
sive expropriation of the land was carried out and the roads that connect it to the city had been built. All of the buildings were designed by local architects. ${ }^{22}$

Figure 2

The construction of the Naval Institute's round pool, HR-BI- photo collection-B3-32, not dated but before 1955, eng. Špehar

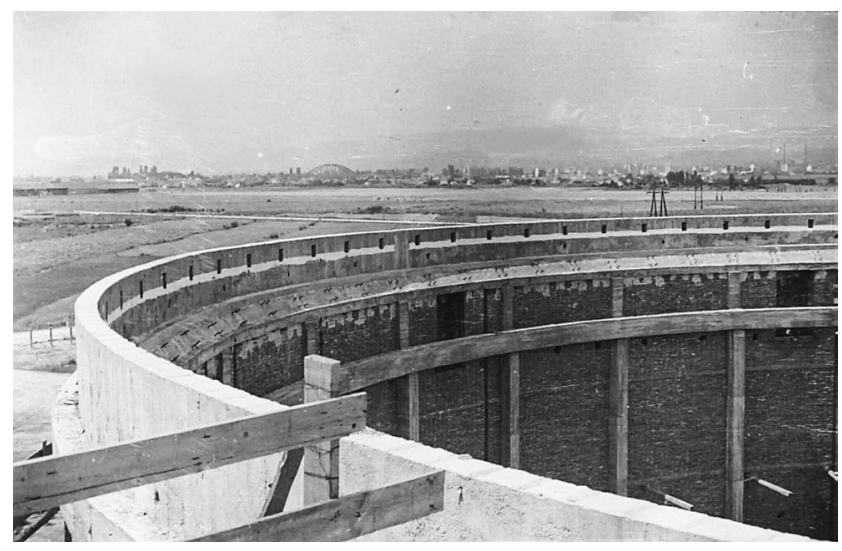

Source: HR-BI- photo collection-B3-32, not dated but before 1955, eng. Špehar

After becoming a mayor in late 1952, Većesalv Holjevac continued engineering the construction of the infrastructural projects south of the river Sava. The following four moves were outlined in the Annual Report of the President of the city authorities in 1954 as the General Working Guidelines for 1954: ${ }^{23}$ the territorial division of the city, the construction of the Bridge of Freedom, the relocation of Zagreb Fair, and the construction of the thermal power plant with the heating plant.

He began with a territorial reorganization of the city. During 1953, he initiated the division of the city into municipalities, ${ }^{24}$ which would later enable the incorporation of the municipality of Remetinec, ${ }^{25}$ the future location of South Zagreb, thus preparing for the further expansion of the city's territory to the south. The crucial strategic

22 HR-BI-In Šilovićs letter to Inženjersko projektni zavod, it is written that eng.Tonković assured superiors in Belgrade that the local architects were able to design the Naval Institute and there was no need to hire German architects, 29.6.1950.

23 HR-DAZG-37-NOGZ-1954/I, sig. 38; Record of the 22st city assembly NOGZ, 25.1.1954. President's Annual Report about the work of NOGZ in 1953, 19.01.1954. p.44/27-28.

24 HR-DAZG-37-NOGZ-1953, sig.341; Record of the 8th city assembly of the city council and the council of manufacturers NOGZ held on the 22. and 26.5.1953; Report on the proposal for Zagreb's new territorial division; p.(5-6)279-280 and 299-399; Record of the 10th city assembly of the city council and the council of manufacturers NOGZ held on the 1.7.1953; It is decided that municipality (općina) is a basic city unit. p. (3) 345

25 HR-DAZG-37-NOGZ-1954/I, sig. 38; Record of the 22st city assembly NOGZ, 25.1.1954. President's Annual Report about the work of NOGZ in 1953. 19.01.1954. p.44/28 
move across the river was the construction of the Bridge of Freedom (Figure 3) that connected the city in the north with the airport and the Fair in the south. In 1953, the mayor saw "the construction of new a modern bridge over Sava River" as an important task that would open "the possibility of realizing the perspective of the city development towards the south." ${ }^{26}$ The plans for the bridge started in 1950 and the bridge opened in 1959 (Bobovec et al., 2012:188), while the decision for its construction was made in $1954 .{ }^{27}$ The drawings of the bridge sections made in 1956 clearly illustrate that the plumbing that passed through the bridge was intended for a large part of the city, and could be added if needed. ${ }^{28}$

\section{Figure 3}

The construction of the Bridge of Freedom, HR-MGZ-PA [41.310], 1958, Milan Pavić

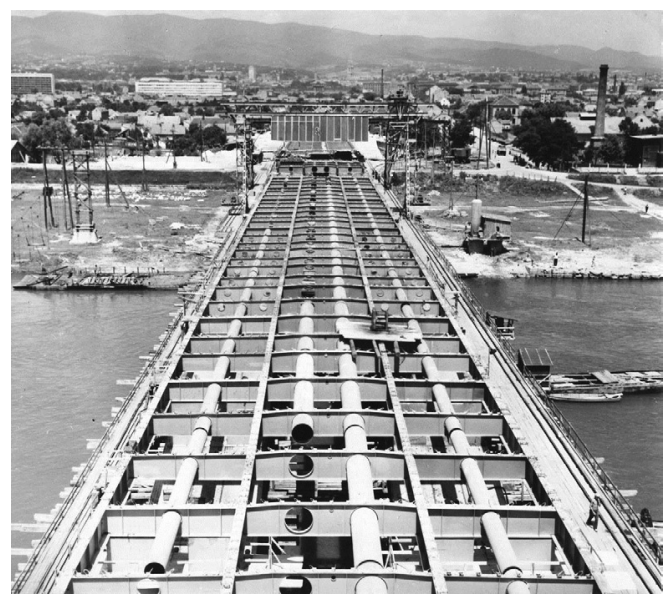

Source: HR-MGZ-PA [41.310], 1958, Milan Pavić

Upon his arrival, being fully aware that the Zagreb Fair (Figure 4) was the basic core of the city's commercial life with a long tradition, ${ }^{29}$ the mayor asked for an economic study for the construction of Zagreb Fair south of the river ${ }^{30}$ with the intention of

26 HR-DAZG-37-NOGZ-1954/I, sig.38; Record of the 22st city assembly NOGZ, 25.1.1954. President's Annual Report about the work of NOGZ in 1953. 19.01.1954. p.44/30

27 HR-DAZG-1122-ZGD-MOST SLOBODE-TRNJE, sig. 3556, the Building permit for the Bridge of Freedom (5570-VII-1-1955) is dated 15.4.1956. It is written that the decision about its construction was taken in 23.12.1954 and was asked for in 14.5.1955 (br. 34989/55)

28 HR-DAZG-1122-ZGD-MOST SLOBODE-TRNJE, sig. 3556/1,-the Bridge of Freedom, technical drawings dated August, 1956; cross section of the bridge dated 30.6.1954.

29 HR DAZG-37-NOGZ-1954/I, sig.38; Record of the 22st city assembly NOGZ, 25.1.1954. President's Annual Report about the work of NOGZ in 1953. 19.01.1954. p.44/29.

30 HR DAZG-37-NOGZ-1953, sig.37; Record of the 5th city assembly NOGZ, 20.3.1953. p.4 Assembly needs to be acquainted with the economic analysis of the relocation of Zagreb Fair on the south. 
relocating it there. In early 1954 , the local authorities decided to relocate it to the right bank of the river. ${ }^{31}$ Throughout the city's history, Zagreb Fair was dislocated five times in one-hundred years, always to the city's outskirts as an instrument of the development of the city (Blau and Rupnik, 2007; Bobovec et al., 2012; Knežević, 1996). This time, the International Fair" "brought technical infrastructure (gas, electricity, water, and transportation) to the area south of the river, something the city had neither the authority nor the means to achieve on its own" (Blau and Rupnik, 2007:221), and thus, it has indeed served as an urban generator for the further construction of Novi Zagreb.

Figure 4

The start of Zagreb Fair's construction, HR-MGZ-PA [41.284], 1956; Šime Radovčić

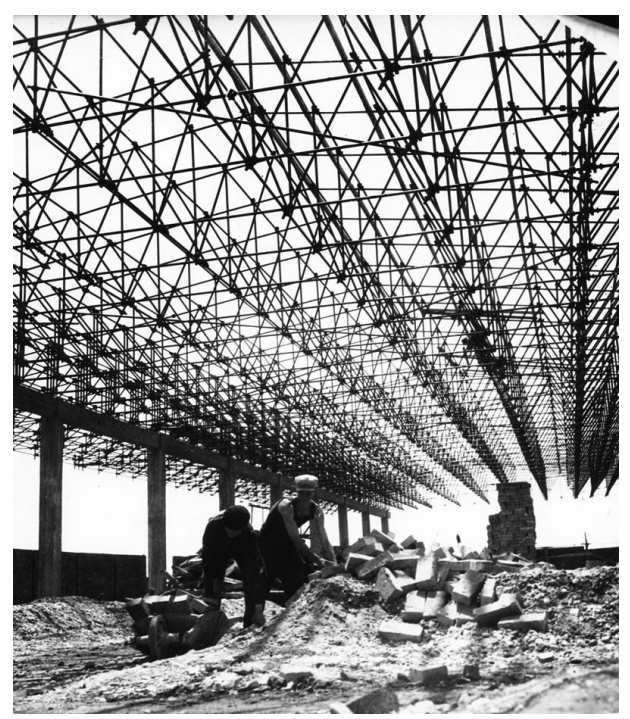

Source: HR-MGZ-PA [41.284], 1956; Šime Radovčić

Another strategic decision was to build a thermal power plant (Figure 5) in close proximity to the future Novi Zagreb. Wanting to keep the character of the industrial and commercial center, the city authorities were aware that Zagreb needed to provide a sufficient supply of electrical energy that would enable efficient functioning

31 HR-DAZG-37-NOGZ-1953,-sig.341; Record of the 14th city assembly of the city council and the council of manufacturers NOGZ held 28.12.2953; The relocaton of Zagreb Fair across the river Sava is discussed. Mayor is authorized to negotiate with the Federal executives in Belgrade about the relocation, p.428.

HR DAZG-37-NOGZ-1954/I, sig.38; Record of the 21st city assembly NOGZ, 12.1.1954. The location for the new Zagreb fair will be on the south bank of the river Sava, p. 3-4.

32 International Zagreb Fair opened in 1956. Thanks to the geopolitical neutrality of Yugoslavia (member of the Non-Alignment movement), Zagreb Fair was the only fair at which USA and the USSR exhibited together during the Cold War (Blau and Rupnik, 2007). 
of its industry. ${ }^{33}$ After the analysis affirmed that Zagreb was indeed a proper location for a new thermal power plant, in 1954, they have strategically approved its location on the northern bank of the Sava River, ${ }^{34}$ in close proximity to the future Novi Zagreb in the south and the new industrial zone in the east. Not only would the Savica power plant later provide heating for Novi Zagreb, but due to its construction the electrification of the whole city was redone, including laying cables underground, ${ }^{35}$ which facilitated the city's development towards the south.

Figure 5

Thermo plant on Savica, Zagreb, HR-HDA-1422_P-752-13, 24.10.1960, Mato Pintar

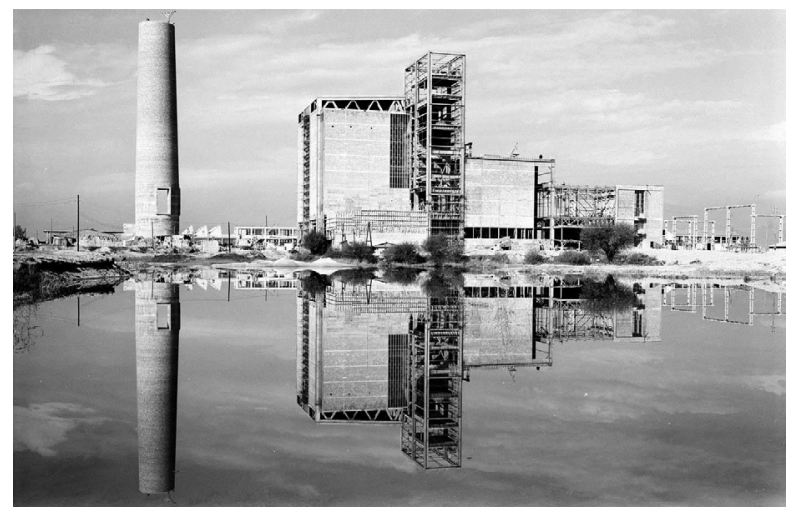

Source: HR-HDA-1422_P-752-13, 24.10.1960, Mato Pintar

Around the same time, there were several other infrastructural works that took place in the south such as the Hippodrome ${ }^{36}$ (1952), Lake Bundek ${ }^{37}$ (1958), and the educational complex of the GŠC (1956). In the mid-1950s, the first experiments in prefabrication techniques took place on the collective housing buildings in Naselje februarskih žrtava (Strukić, 2010:16), followed by housing construction in Savski Gaj (1957), which preceded the construction of the first entirely planned neighborhood

33 HR DAZG-37-NOGZ-1954/I, sig.38; Record of the 22st city assembly NOGZ, 25.1.1953. President's Annual Report about the work of NOGZ in 1953. 19.01.1954. p. 44/29.

34 HR-DAZ-1122-ZGD-TERMOELEKTRANA ZAGREB II sig.3587, A temporary approval of the location for the Thermal power plant was issued on 13.8.1954, nr. 9956-VII-1-1954; A final approval of the location was issued on 6.8.1956. nr. 3918-VIII-1-1956; Thermal power plant Zagreb II, a building permit for $30 \mathrm{kV}$ plant, 22.7.1960

35 HR DAZG-1122-ZGD-TERMOELEKTRANA ZAGREB II sig. 3584 The building permit for laying cables 30/10 kV underground (Toplana-ukl.VI-ukl.II) nr.08/2-23825/1-1959. dated 21.8.1959

36 Before becoming a hippodrome in 1952, the place was a garbage dump (Gulin Zrnić, 2009).

37 HR-GUSPRG-technical documentation-0.10.2-5.1-bathing resort, The Lake Bundek Project, dated 30.06.1958, Zagreb's Urban Planning Department. 
Micro-rayon Novi Zagreb in 1959. The construction of the neighborhoods intensified in 1960s and the 1970s, which eventually led to the construction of the new modernist city (Figure 6).

Figure 6

Novi Zagreb in the mid-1990s; Airplane photographs of Novi Zagreb, (Andre Mohorovičić et al., 1999:167)

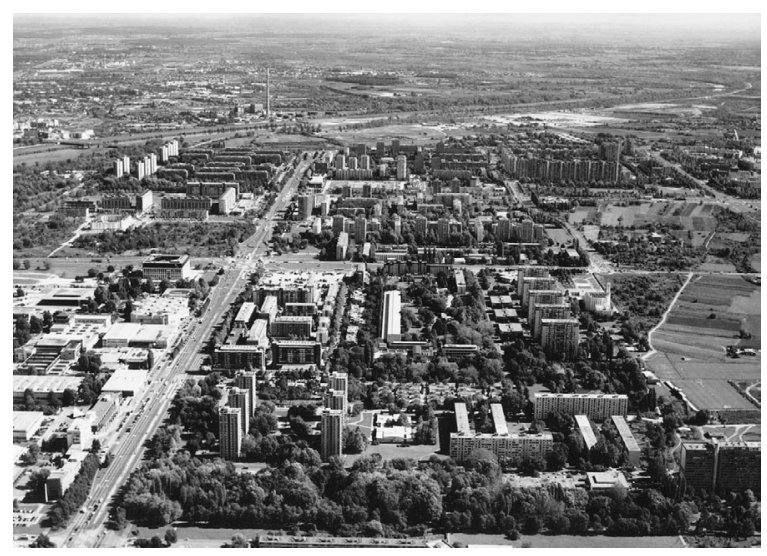

Source: Andre Mohorovičić et al., 1999:167

There is a considerable gap between what has been written about Novi Zagreb (Domljan, 1969; Fisher, 1985; Franković, 1985; Premerl, 2003; Radović Mahečić, 2003; Gulin Zrnić, 2009; Bobovec et al., 2012; Križić Roban, 2012) and my findings. The archival research revealed that there was a series of seemingly unconnected infrastructural projects south of the river Sava that started in the late 1940s and early 1950s, which enabled the later construction of the Novi Zagreb neighborhoods, and four of them were presented in one single document. Finding out that this part of the city had begun to be built a decade earlier than the existing Plan for South Zagreb situates it in a different socio-political context. I argue that all five strategic moves were part of a single autonomous project, a unique endeavor, which had the idea of a modernist "functional city" as a guiding principle, which is why I refer to it as a city, rather than just a part of the city. Even though there was no plan drawn up, there was a strategy by which local authorities had the intention to build a modernist city. This scheme reminds us of the construction of Lenuci's Horseshoe, ${ }^{38}$ whose plan did not exist on the paper until it was actually constructed on the ground, implying that the city authorities might have, again, used the same well-known planning strategy, which had been previously used under unstable political conditions (Blau and Rupnik, 2007).

38 Lenuci's Horseshoe is the most significant urban ensemble in Zagreb's history, and has a very strong presence in the collective consciousness of the city. It was realized from the 1880s until the 1920s, and consists of a series of parks with public buildings carved in Zagreb's Lower Town block tissue, which looks like Vienna's Ring of Parks. Although attributed to Lenuci, a larger group of people was involved in planning and completing the project (Knežević, 1996, 2011). 


\section{Novi Zagreb - An Autonomous Project?}

In this section of the paper, I will use Kaminer's theory to test my hypothesis that Novi Zagreb was an autonomous project. This theory posits that the transformation of the discipline of architecture has the capacity for autonomous transformation during the times of social crisis, by withdrawing itself into the realm of the "ideal", and resuscitating itself in order to be able to accommodate a new social order. The sequence of reactions that the discipline takes on the route to recovery starts as a "withdrawal, escapism, resistance, resuscitation and finishes with the acceptance" (Kaminer, 2011:7) of the new socio-political and economic circumstances. My hypothesis is that the construction of Novi Zagreb was the final step on the architecture's route of recovery, while its conception was the result of the resistance of architecture towards the imposition of the Socialist Realist aesthetic doctrine. Juxtaposing the development of architecture in Zagreb with its social, political and cultural context would reveal the ways in which they influenced each other. ${ }^{39}$

Throughout history, Zagreb has gone through frequent political changes, yet showed surprising continuity in "artistic production" (Šerman, 2007:138). The city had its centers of power located elsewhere, be it Vienna, Budapest or Belgrade which forced the local authorities to develop autonomy in order to negotiate the city's development. Prompted by the early 19th century national movement, a Croatian peripheral society, which at the time was part of the Habsburg Empire, strived for national integration. In achieving this, Croatia needed a national center: a recognizable place for its social and cultural representation. Hence, the city's further development was conditioned by "the perception of Zagreb as a Croatian metropolis" (Rogić, 2003:17). The city, instead of reflecting social circumstances, became a project for changing those circumstances. Zagreb's peripheral position enabled "intensification of culture" (Blau and Rupnik, 2007:14) that could not be so easily controlled by the ruling power, as military and economic forces could be, which enabled the city to become the locus of architectural innovation and experimentation.

I argue that the transformation of the discipline of architecture, which culminated with the construction of Novi Zagreb, started earlier, with the social crisis due to the dissolution of the Austro-Hungarian Empire in 1918 at the end of the WWI. In 1918, Croatia became part of the Kingdom of Serbs, Croats, and Slovenes, and the two following decades were marked by political instability, mainly because of the "conflict between the Serbian-dominated central government and Croatia", which was an economically more "developed part of the Kingdom" (Blau and Rupnik, 2007:97). During that time, Zagreb had to cope with the rapidly growing number of its inhabitants, the post-war housing crisis, and the economic consequences of the 1929-1933 world crisis. Those major political and social changes, which were followed by a period of economic crisis, launched the inherent autonomous disciplinary transformation of architecture that starts with the withdrawal into the realm of the "ideal", adjusting "its procedures, methodologies and self-understanding in order

39 This section of the text, in great part, relies on Blau and Rupnik, 2007 and Šerman, 2007. 
to accommodate changes in society" (Kaminer, 2011:7). The modern architecture which took hold in Zagreb before WWI in the work of Viktor Kovačić, a disciple of Otto Wagner, found itself inadequate in answering the demands of the new capitalist society. It still did not develop the methodologies which could cope with the then urgent problem of providing a large number of housing units, and instead of actively participating in the construction of a new reality, it withdrew from it, reinventing itself by adjusting its operations and overall agenda to the new circumstances.

The crucial move towards the redefinition of the discipline of architecture was establishing the institution of public architectural competition as an obligatory operation $^{40}$ for the construction of all buildings of major significance, and for the urban master plans. Hence, both local and international competitions in Zagreb, during the 1920s and 1930s, stimulated architectural experimenting and innovation through "paper architecture," which strongly influenced the formation of the discipline of architecture. What followed was the foundation of several institutions; two schools of architecture: the Technical University in 1919 and the Master Class (Meisterschule) of the Academy of Fine Arts in 1926, directed by Drago Ibler, which would educate the following generations of Croatian architects, and two institutions: the city building department in 1928, directed by Ivan Zemljak, and the Regulation Office in 1928, directed by Stjepan Hribar, which further contributed to the development of the discipline of architecture.

Besides establishing the formal institutions, there were plenty of informal cultural groups and affiliations within those groups which contributed to the discipline's development. Although the production of architecture was not large, there was a wide "range of experiments and original work, as well as intensity of architectural events a such" (Radović Mahečić, 2007:13). The vibrant cultural climate of the 1920s and 1930s in Zagreb was initiated with the flourishing of avant-garde periodicals such as Aleksićs Dada journals and Ljubomir Micićs Zenit, in which Josip Seissel begins with abstract experiments in the early 1920s. A close collaboration of young Croatian architects with international teachers such as Loos, Le Corbusier, Poelzig, and Beherns, resulted in significant architectural production in Zagreb during the interwar decades, and in great part contributed to an early emergence of the architecture of functionalism and international modernism in Zagreb. A close associate of Le Corbusier, Ernest Weissmann (Bjažić Klarin, 2005), initiated an international collaboration of a group of architects from Zagreb with CIAM. ${ }^{41}$ As a national group

40 In 1920, the Association of Yugoslav architects adopted the new regulations for architectural competitions which included the obligation of organizing public competitions. Since 1905, members of the Club of Croatian architects demanded the obligation of public competitions for all mayor buildings, and recognition of architecture as art (Radović Mahečić, 2007).

$\mathbf{4 1}$ CIAM (Congrès Internationaux d'Architecture Moderne), an organization of European architects gathered around Le Corbusier in 1929, was in search of a new city planning methods for a modern way of life. At the CIAM congress IV, the contemporary cities were analyzed and the concept of a "functional city" was put forward, which after WWII became a model for postwar city planning (Mumford, 2000). 
of CIAM for Yugoslavia, the Zagreb Group ${ }^{42}$ prepared the analysis of the living conditions in rapidly growing Zagreb, which was one of the 33 examined cities on the CIAM congress IV, titled "Functional City," in 1933. Vladimir Antolić, who took part in the congress, together with Ernest Weissmann and Bogdan Teodorović, not only presented the idea of the "functional city" to a wider public by giving a lecture upon his return, but also immediately implemented its principles in the 1936 Regulation Plan for Zagreb. Realizing that architecture has the power and potential to change society, architects suddenly became aware of its responsibilities. In fact, the whole cultural scene was permeated with social ideas and the matters of collectivity. Architect Drago Ibler, who studied at Poelzig in Berlin, gathered a group of progressive artists into the Zemlja ${ }^{43}$ (Earth) Group, which was highly socially engaged. The group struggled against the imposition of the Socialist Realist doctrine, just as their intellectual "godfather" (Blau and Rupnik, 2007:100), writer Miroslav Krleža, did in the literature (Lasić, 1970), which led to the banning of the group in 1935. However, its members continued collaboration with some members of the Zagreb Group, and developed new strategies for cooperative housing in Zagreb in the late 1930s (Blau and Rupnik, 2007:170).

After WWII, Croatia became a part of the multinational, partisan-run Federal People's Republic of Yugoslavia. As in other Eastern Bloc countries, the regime imposed upon art with "Socialist Realism as the official poetics of the ruling socialist system" (Šerman, 2007:138). Yet, in contrast to the other socialist countries, the regime's pressures did not last as long due to the radical break of Tito with Stalin in 1948, and the consequent ejection from the Cominform, which positioned Yugoslavia "on a fairly precarious line between East and West" (Šerman, 2007:137) and soon enabled moderate liberalization of the arts. In the early 1950s, searching for economic stabilization, the regime focused on creating an independent route for socialism based on autogestion, ${ }^{44}$ and the ideological pressures on art started to diminish. Yugoslavia opted for a geopolitical neutrality and therefore wanted to "portray itself in a way that could work for both sides" (Šerman, 2007:138). A leading Croatian writer, Krleža, who became a prime literary and cultural authority in Yugoslavia, officially announced the liberalization of the arts from the regime's control and Social Realist poetics in the speech at the 3rd Congress of the Union of Yugoslav Writers held in Ljubljana in 1952, by pronouncing the "freedom of choice of artistic expression and

42 Members of Zagreb group were Vladimir Antolić, Viktor Hećimović, Zvonimir Kavurić, Josip Pičman, Josip Seissel, Bogdan Teodorović, and Ernest Weissmann, (Bjažić Klarin, 2005).

43 Zemlja (1929-1935) founding members: Drago Ibler, architect, sculptors: Antun Augustinčić, Frano Kršinić, painters: Vinko Grdan, Krsto Hegedušić, Leo Junek, Omer Mujadžić, Oton Postružnik, Kamilo Ružička, and Ivan Tabaković

$\mathbf{4 4}$ The Yugoslav project of autogestion (samoupravljanje), whose ideological roots date back to the 19th century (Mikhail Bakunin, Pierre-Joseph Proudhon, Peter Kropotkin, Georges Sorel, etc). was underpinned with two pilars: decentralization and establishing workers' councils in state companies as "organs of socialized labour." This was a foundation for the establishment of the system of self-management that was introduced in the 1974 constitution. The project was significant because it set up the socio-economic basis for "withering away of the state" and fostered a comprehensive democratization of society (Ronneberger, 2009:90-94). 
a possibility of relying on (and using) Western cultural models" (Šerman, 2007:140). A sign of the liberalization of arts was the emergence of the group of progressive architects and artists called EXAT ' $51^{45}$ who promoted synthesis of all arts, a total freedom of artistic expression, and abstract art which was not preferred by the regime.

However, the immediate post-war period (1945-1952), when the ideological pressures on art were still strong, was crucial for defining the idea of a modern city in Yugoslavia. The regime's imposition of Socialist Realist poetics intensified the struggle for autonomy in all spheres of art, including architecture, which resisted the regime's pressures through both drawings and in the theoretical discourse. For the majority of Croatian architects, "the newly established socialist system must have appeared as the fulfillment of a great deal of their strivings: it suited their leftist ideas properly and it gave them a collective society as their long-awaited client. What was most rewarding is that they, thereby, had the mechanisms of architectural intervention already developed and prepared. From their point of view, the architecture of functionalist modernism was more than an appropriate tool in such radically new social circumstances" (Šerman, 2007:140). Since there was no competition for the urban development of Zagreb, the majority of Croatian architects took part in the competitions for New Belgrade, a new administrative capital city, and won two out of three first prizes (Ivanković and Obad Šćitaroci, 2011). Even though the competition $^{46}$ was organized for the two party and state buildings, and provided the initial layout of the city, ${ }^{47}$ the architects were asked to develop urbanistic schemes compliant with their respective proposals for the buildings (Blagojević, 2004). As the imperative of Socialist Realist poetics was still quite strong, the competition brief for the buildings of the Central Committee of the Communist Party of Yugoslavia and the Presidency of Government of Federal People's Republic of Yugoslavia asked for a "monumental and representative architecture" (Blagojević, 2004). Although some proposals faltered in design from modernist to more monumental (Šerman, 2007:141), most of the competition entries demonstrated modernist poetics, which was a decisive shift from then dominant Social Realist poetics towards a new discourse of modern architecture appropriate for the changed socio-political and economic conditions.

After the competition, the resistance against Socialist Realist poetics continued in the theoretical discourse. While the Croatian architects were convinced that modernist functionalism was the most appropriate style for the construction of new socialist reality, the official party circles labeled it:

...as empty, fruitless and purely mechanical, devoid of inner human substance and as such a clear signifier of decadent bourgeois West. To these

45

The members of Experimental Atelier ' 51 were architects: Bernardo Bernardi, Zdravko Bregovac, Zvonimir Radić, Božidar Rašica, Vjenceslav Richter, Vladimir Zaharović; painters: Vladimir Kristl, Ivan Picelj and Aleksandar Srnec (Denegri, 2000:55).

46 The competition started in late 1946, and was finished in May of 1947 (Blagojević, 2004:40).

Nikola Dobrović sketch for Novi Beograd, (Blagojević, 2004:207). 
accusations the Croatian architectural theorist Andre Mohorovičić, a convinced communist himself, replied by constructing a breakthrough-term of a "generalized" or "comprehensive functionalism," as a unique, broad concept which embraced (as Mohorovičić claimed Croatian functionalism had always done), besides the necessary layers of function, construction and economy, so many other levels such as aesthetics, history, regional morphology, politics, culture and psychology. [...] In that way, Mohorovičić claimed, although Croatian modernism indeed did rely on international, Western models, it "transcended" the mere mechanical, technical dimensions and became a sort of "humane functionalism", "functionalism with human face", and was thus fully in line with the broad humanistic aspirations of the ambitious socialist system (Šerman, 2007:141).

Mohorovičić, an influential architect and theoretician at the time, derived the concept of "comprehensive functionalism" by analyzing the city throughout different historical epochs with its means of production and social structures, concluding that different societies had different architectural representations. He claimed that city planning was "the most obvious affirmation of design arising from general conditions of the social structure" (Mohorovičić, 1947:7) and saw it as the most immediate reflection of a society. Consequently, he considered that architectural representation of a modern city should adequately represent a new prosperous socialist society.

Modern city has to logically reflect ultimate life energy dynamics of contemporary social order. The collective power of working masses in movement forms its arteries, erase trivial individualities, characterize the direction of compositional expression of its squares, theatres, stadiums, airports, factories, settlements, parks etc. Unprecedented working rhythm forms labor facilities, and caesuras in this rhythm materialize in recreational facilities. These characteristics must be included in architectural design (Mohorovičić, 1947:6).

Putting forward the concept of "comprehensive functionalism" in the first number of the newly founded journal Arhitektura in 1947, immediately after the pages on the Five Year Plan for the country's construction, implicitly suggested the approval of functional modernism as the official poetics. This was followed by a fierce critique by Belgrade architect Maksimović (1948) in Arhitektura, which further polarized the positions between Socialist Realism, imposed by regime, and modernism, advocated by Croatian architects as a logical outcome of historical development of architecture in Croatia. Maksimović's critique was concluded by editor's affirmation (Šegvić, 1948:80 $)^{48}$ of Mohorovičićs position and can be considered to be the completion of the short post-WWII period during which Croatian architects vigorously resisted

48

"Our theoretical position on the issues of architectural design has to be based on the analysis of contemporary socialist socio-economic system, on the analysis of its organization, analysis of development of its capital assets, analysis of its ideological progress. The totality of all these factors forms the foundation for the development of contemporary architectural design, which has to be the expression of its time" (Šegvić, 1948:80). 
strong ideological pressures, both in the New Belgrade competitions and in the theoretical discourse, and managed to define "comprehensive functionalism" as a poetics that would adequately represent new socialist order. For city planning, this meant the acceptance of modernist concept of "functional city" (and Le-Corbusiers ideas of the city as idealized image of a new social model) as a paradigm for modern city planning in Yugoslavia.

Mohorovičić, who in addition to being theoretician, also took an active part in Zagreb's urban planning after the war ${ }^{49}$ (Ivanković and Obad Šćitaroci, 2011:364, 367), was wholly aware of the urgent need for housing and the impossibility of meeting of the demands on Trnje, as proposed by existing 1936 and 1947 Regulative plans. As soon as the political pressures started to diminish in 1952, he wrote:

The development of new Zagreb has to be situated on the new grounds which would allow the free expression of new urban planning ideas which will meet functional demands of life in a new social reality. At the same time, it will interpret emotions of artistic experience expressed in urban and architectural compositions of socialist realism[...] Zagreb is currently in the phase of an impending crystallization and establishment of the urbanist concept of its new parts. This phase should see its perspective established through a scientific analysis tied with the new conditions of development in the framework of socialist society and embrace it with an adequate artistic expression both in urban and architectural design (Mohorovičić, 1952:49).

Bearing in mind that he was a zealous advocate of functional modernism, meaning that he was acquainted with the idea of the "functional city," it can be indeed assumed that it was Mohorovičić who suggested further development across the river (Ivanković, 2006:185).

In the same year (1952), after strong political pressures abated, Većeslav Holjevac became the mayor of Zagreb. At that time, Zagreb had grown at a rapid pace because of the immigration prompted by industrialization. The new class of workers that was to build the new socialist society required a large number of housing units, and Zagreb was in dire need of a new plan. However, there was no competition for the development of Zagreb, which might suggest there was little political will from the regime to develop it. Being aware of the lack of the regime's political will for Zagreb's expansion (Rogić, 2003:31), and having the experience of operating under unstable political conditions, the local authorities decided to make a series of strategic moves in the early 1950s which would open up the road for the construction of South Zagreb. Although the mayor's importance in carrying out the project is indisputable, and it is often attributed to him, I assume that a larger group of architects and intellectuals was involved in engineering this endeavor, just as behind

49 Mohorovičić was the frist Secretary of Temporary National Committee of Zagreb - Narodni gradski odbor Zagreba (GNOZ) since 27.5.1945 (Ivanković and Obad Šćitaroci, 2011:364) and he actively takes part in teritorial division as well as controlling the construction projects. 
the conception of Lenuci's Horseshoe stood a larger group of people (Knežević, 2011:41-42). The majority of Croatian architects active in the interwar period, who developed the tools of functional modernism, practiced the new city planning methods, and were aware of Zagreb's urgent need for housing, continued their activity in the post-war period. To name but a few: Zdenko Strižić, Poelzig's student in the 1920s, who worked in the City Regulation Office and was a member of the Zemlja group during the 1930s, after WWII became a teacher at the Faculty of Architecture educating the new generations of architects which would not only build South Zagreb $^{50}$ but also change the direction of art in Croatia, ${ }^{51}$ because all of the architects members of EXAT'51 were his students; Vladimir Antolić, who took part in the CIAM congress IV in 1933, was the main city planner until 1953; Drago Ibler, founder of the Zemlja Group and Meisterschule, continued to teach generations of post-WWII students; Josip Seissel who was a major contributor to the avant-garde Zenit movement in the 1920s, was a member of Zagreb Group and worked in City Regulation Office in the 1930s, after the war continued working as a professor at The Faculty of Architecture in Zagreb at the Department for Urban Planning; Miroslav Krleža, who zealously struggled for the autonomy of literature and the arts in the interwar period, and after the WWII became the primary literal and cultural authority in Yugoslavia, took part in architectural competitions as a jury member, became a personal friend of Tito and mayor Holjevac.

It seems that those intellectuals, and others not mentioned here, formed a sort of local autonomy based on interpersonal relationships, and Foucauldian disciplinary "counter-law" mechanism based on "private-links" came into play overpowering the regime's lack of will to develop Zagreb across the river. A series of strategic decisions were made to realize a plan for South Zagreb which, similar to the Horseshoe, did not actually exist on paper until after all of the infrastructure for the city was already in place on the ground. In this respect Novi Zagreb can be considered as a paradigmatic example of an autonomous project, because the inherent properties of the discipline of architecture overpowered the external realities, and architecture managed to surmount the political impositions of the ruling regime (as it could overrule any other regime) by constructing a new modernist city.

\section{Conclusion}

In the mid-1960s, a city for 250,000 residents was being built on the southern side of the Sava River. Although there was no competition for the urban development in Zagreb immediately after WWII, as in Belgrade, the archival research and the interviews with the architects that took part in the construction show that the local authorities made a succession of strategic decisions about the construction of

50 Strižić was professor to almost all of the participants I interviewed up until now (except one, but Strižić was not his professor): Josip Uhlik, Nada Uhlik, Bogdan Budimirov, Boris Magaš and Neven Kovačević; and all of them consider him as the professor who formed them. 51 Strižić was professor at Engineering Faculty of Zagreb University to all architects members of EXAT'51 (Ceraj, 2011:19). 
infrastructural projects in the late 1940s and during the early 1950s, almost a decade before the existing Plan for South Zagreb (Kolacio, 1962), which enabled the construction of the city. Therefore it seems highly likely that the infrastructure planning, engineered with the intention to build a modernist city across the river, was an autonomous project.

That Novi Zagreb was an autonomous project means that there was a strategy which, regardless of the ideological pressures, enabled architectural thought to realize a distinct idea of the city, instead of just confirming its existing conditions. The carrying out of this strategy was enabled due to architectural autonomy, the capacity of the discipline of architecture to transform and reinvent itself in times of social upheavals, which gives architecture the possibility to address social issues responsibly. Drawing upon the concept of architectural autonomy, I examined the transformation of architecture within the social, political, and cultural context in post-war Zagreb, when the regime's pressures on art were quite strong. Croatian architects defined the idea of the modern city in Yugoslavia in the immediate post-WWII period by resisting the regime's pressures for Social Realist poetics. There is evidence of their resistance towards the imposition of Socialist Realism, both in the competitions for New Belgrade's buildings and within the theoretical debates, resulting in official acquiescence in the modernist paradigm of the "functional city" as a model for the construction of the new socialist reality. At the same time, in the early 1950s, shortly after the liberalization of the arts from political influences, the local authorities led by mayor Holjevac envisioned a succession of strategic infrastructural moves which would lead to the construction of a modernist city a decade later.

The case of Novi Zagreb shows that architecture is indeed capable of resisting political authority, and being other than just a mere servant to ideological forces. This example reveals that the actions of Zagreb's architects, who exercised power in a disciplinary manner based on Foucauldian interpersonal ties, succeeded in resisting the political forces. Regardless of the fact that some of them were party members, their professional non-institutional cooperation and their affiliations with other intellectuals, cultural groups and local authorities enabled the realization of their clearly defined ideas based on architectural knowledge. The outcome was the construction of the city that nowadays provides excellent living conditions as opposed to other city parts in Zagreb that came into being by ad hoc planning.

As the discipline of architecture managed to develop autonomously in the post-war period when restricted by authoritarian powers, the question is whether it would be equally able to cope with the other external influences nowadays, such as neoliberal economy or free-market capitalism. The case of Novi Zagreb opens up the possibility for reconsidering architectural autonomy as a means of resistance against the current post-transitional landscapes of spatial disorder in Zagreb. It also shows that the agents which addressed the social issues responsibly were not the institutions, but rather, the architects themselves, with their non-institutional informal cooperation and affiliations with other cultural groups, which implies that the responsibility for carrying out the changes in the contemporary city continues to lie with the architectural profession. 


\section{Bibiliography}

1. Anderson, S. (2002). Quasi-Autonomy in Architecture: The search for an "Inbetween". PERSPECTA, The Yale Architectural Journal, 33.

2. Aureli, P. V. (2009). Chi ha paura della forma? Origini e sviluppo del formalismo nel moderno e La base formale dell'architettura moderna di Peter Eisenman, in: P. Eisenman (Ed.). La base formale dell'architettura moderna. Bologna: Edizioni Pendragon.

3. Aureli, P. V. (2011). The Possibility of an Absolute Architecture. Cambridge MA, USA; London, England: The MIT Press.

4. Banac, I. (1988). With Stalin against Tito: cominformist splits in Yugoslav communism. Cornell University Press.

5. Bjažić Klarin, T. (2005). Zagreb Group - foundation and public activities in Croatian cultural context. Prostor, 13.

6. Blagojević, L. (2004). Strategije modernizma u planiranju i projektovanju urbane strukture i arbitekture Novog Beograda: period konceptualne faze od 1922. do 1962. godine; Doktorska disertacija. Beograd: Arhitektonski fakultet, Univerzitet u Beogradu.

7. Blake, P. (1977). Form Follows Fiasco Why Modern Architecture Hasn't Worked. Boston/Toronto: An Atlantic Monthly Press Book Little, Brown and Company.

8. Blau, E. and Rupnik, I. (2007). Project Zagreb: Transition as Condition, Strategy, Practice. Barcelona: ACTAR.

9. Bobovec, B.; Mlinar, I. and Sentić, D. (2012). Zagrebački Velesajam kao poticaj razvoju novozagrebačkog centra. Prostor, 1 (43) (20): 186-197.

10. Ceraj, I. (2011). Dizajnersko djelo arbitekta Bernarda Bernardija: 1951.-1985. Sveučilište u Zagrebu.

11. Denegri, J. (2000). EXAT '51, nove tendencije; umjetnost konstruktivnog pristupa. Zagreb: Horetzky.

12. Despot, M. (1957). Stambena situacija u Zagrebu traži radikalna rješenja. Čovjek i prostor, 1,3 .

13. Domljan, Ž. (1969). Poslijeratna arhitektura u Hrvatskoj. Radovi Instituta za povijest umjetnosti, (10): 3-45.

14. Eisenman, P. (2006). The Formal Basis of Modern Architecture: Dissertation 1963, Facsimile. Zürich: Lars Müller Publishers.

15. Fisher, M. (1985). Neke primjedbe o oblikovnim značajkama nove izgradnje u južnom Zagrebu. Radovi Instituta za povijest umjetnosti, 9: 88-91.

16. Foucault, M. (1977). Discipline and Punish; The Birth of the Prison; trans. Alan Sheridan. New York: Vintage Books.

17. Franković, E. (1985). Urbanističko planiranje Zagreba od 1945. do 1985. Radovi Instituta za povijest umjetnosti, (9): 85-88.

18. Gulin Zrnić, V. (2009). Kvartovska spika . Značenja grada i urbani lokalizmi u Novom Zagrebu. Zagreb: Naklada Jesenski i Turk.

19. Hays, K. M. (1984). Critical Architecture: Between Culture and Form. Perspecta, 21: $14-29$.

20. Holjevac, V. (1960). ***. Čovjek i prostor, (100).

21. Ivanković, V. (2006). Moskovski boulevard-Ulica grada Vukovara u Zagrebu 1945.-1956. godine Arhitektura i urbanizam na razmeđu Istoka i Zapada. Prostor: znanstveni časopis za arbitekturu i urbanizam, 32 (2): 179-195. 
22. Ivanković, V. i Obad Šćitaroci, M. (2011). Planiranje i gradnja Zagreba 1945.1952. Prostor, 2 (42): 362-375.

23. Jong, C. de, and Mattie, E. (1994). Architectural Competitions 1950-Today. (A. Nanji, Ed.). Köln: Benedikt Tashen.

24. Jukić, T. (1997). Strukturalne promjene rubnib dijelova grada - prilog proučavanju urbanističkog razvoja Zagreba. Zagreb: Arhitektonski fakultet Sveučilišta u Zagrebu.

25. Kaminer, T. (2011). Architecture, Crisis and Resuscitation The reproduction of post-Fordism in late-twentieth-century architecture (1st ed.). Abingdon: Routledge.

26. Kaufman, E. (1985[1933]). Von Ledoux bis Le Corbusier: Ursprung und Entwicklung der Autonomen Architektur (2nd ed.). Stuttgart: Verlag Gerd Hatje.

27. Knežević, S. (1996). Zagrebačka zelena potkova. Zagreb: Školska knjiga.

28. Knežević, S. (2011). Zagreb-grad, memorija, art. Zagreb: Meandar.

29. Kolacio, Z. (1962). Južni Zagreb. Čovjek i prostor, (116).

30. Križić Roban, S. (2012). Obilježja modernosti na području arhitekture, urbanizma i unutrašnjeg uređenja nakon Drugog svjetskog rata, in: L. Kolešnik (Ed.). Socijalizam i modernost; Umjetnost, kultura, politika 1950. - 1974. (pp. 55125). Zagreb: Muzej suvremene umjetnosti.

31. Lasić, S. (1970). Sukob na književnoj ljevici 1928-1952. Zagreb: Liber.

32. Laslo, A. (1984). Internacionalni natječaj za generalnu regulatornu osnovu grada Zagreba, 1930/31. Čovjek i prostor, 370: 25-31.

33. Maksimović, B. (1948). Ka diskusiji o aktuelnim problemima naše arhitekture. Arbitektura, (8-10):, 73-75.

34. Mallgrave, H. F., and Ikonomou, E. (Eds.). (1994). Empathy, Form and Space Problems in German Aesthetics 1873-1893. Santa Monica, CA: The Getty Center Publication Programs.

35. Marinović-Uzelac, A. (1984). Atenska povelja; Što je bila-Što jest-Što će biti. ARHITEKTURA; Časopis Saveza arbitekata Hrvatske, (189-195): 24-31.

36. Mohorovičić, A.; Ekinović, S.; Hrg, S.; Premerl, N.; Dakić, S.; Žuljić, S. (1999). Zagreb, tisucljetni grad za novo tisućljece; Zagreb, a millenium-old city for the new millenium. Zagreb: Studio Hrg.

37. Mohorovičić, A. (1947). Teoretska analiza arhitektonskog oblikovanja. Arhitektura, (1-2): 6-8.

38. Mohorovičić, A. (1952). Analiza historijsko-urbanističkog razvoja grada Zagreba (287th ed., pp. 27-51). Yugoslav Academy of Arts and Science.

39. Mumford, E. P. (2000). CIAM Discourse on Urbanism 1928-1960. The MIT Press.

40. Petrović, B. (1958). Osvrt na urbanistički razvoj Zagreba. Čovjek i prostor, (58), 2.

41. Premerl, T. (2003). Zagreb, grad moderne arbitekture: stoljeće zagrebačke arbitekture (Vol. 11). Zagreb: Durieux.

42. Radović Mahečić, D. (2003). Architecture and Modernization of the City, in: F. Vukić (Ed.). Zagreb, Modernity and the City. Zagreb: AGM. (pp. 62-84)

43. Radović Mahečić, D. (2007). Modern Architecture in Croatia 1930's. Zagreb: Institute of Art History; Školska knjiga.

44. Rogić, I. (2003). What has happened in Zagreb, in: F. Vukić (Ed.). Zagreb, Modernity and the City. Zagreb: AGM. (pp. 16-38) 
45. Ronneberger, K. (2009). Henry Lefebvre and the Question of Autogestion, in: S. Bitter and H. Weber (Eds.). Autogestion; or Henri Lefebure in New Belgrade (Filip., pp. 89-117). Berlin: Sternberg Press.

46. Strukić, K. (Ed.). (2010). Pola stoljeća Trnskog - priča jedne generacije. Zagreb: Muzej grada Zagreba.

47. Šegvić, N. (1948). Ka diskusiji o aktuelnim problemima naše arhitekture. Arhitektura, 8-10, 76-80.

48. Šegvić, N. (1956). Na temu 51.576 stanova godišnje. Arbitektura, (1-6), 5-6.

49. Šerman, K. (2007). The new reality and the phenomenon of abstraction: on some aspects of Croatian Architecture in the 1950s and 1960s. ARCHITEKTÚRAEURBANIZMUS, Journal of architectural and town-planning theory, 41, 138.

50. Vidler, A. (2002). The Ledoux Effect: Emil Kaufmann and the Claims of Kantian Autonomy. Perspecta, Mining Autonomy, (33), 16-29.

51. Zaključci prvog jugosl. savjetovanja o stambenoj izgradnji i stanovanju u gradovima. (1956). Arbitektura, (1-6), 30.

\section{Sources}

1. State Archives in Zagreb (Državni arhiv u Zagrebu) HR-DAZG

2. Archives of the City Office for Department for Strategic Planning and Development (Gradski ured za strategijsko planiranje i razvoj grada) HR-GUSPRG

3. The Zagreb City Museum - photo archive (Muzej Grada Zagreba - fototeka) HRMGZ-PA

4. Naval Institute Archive (Arhiv Brodarskog Instituta) HR-BI

5. Croatian State Archives (Hrvatski Državni Arhiv- Fond fotografija Agencije za fotodokumentaciju) HR-HDA-1422 
Prethodno priopćenje

Dubravka Vranić

FORMA studio, d.o.o., Zagreb, Hrvatska

e-mail:dubravkavranic@gmail.com

Otpor arhitekture političkom režimu/ima: slučaj Novog Zagreba

\section{Sažetak}

Ovaj članak koristi primjer Novog Zagreba da bi ispitao u kojoj mjeri se arhitektura može oduprijeti političkoj vlasti. Iako su okolnosti njegova nastanka još nejasne, tvrdim da je nastao kao rezultat otpora arhitekture političkim snagama. Za razliku od postojećih studija koje tvrde da su prvi urbani kompleksi Brodarskog Instituta i Velesajma sagrađeni s južne strane rijeke Save bez namjere da se gradi stanovanje, moja pretpostavka je da su oni građeni kao dio projekta za izgradnju modernističkog grada od samog početka, puno prije prvog Plana za Južni Zagreb iz 1962. Arhivsko istraživanje i dubinski intervjui pokazuju da je većina strateških odluka o infrastrukturnim projektima, koji su omogućili izgradnju modernističkog grada desetljeće kasnije, donesena u kasnim 1940-im i 1950-im. Istovremeno, u kasnim 1940-im, odupirući se nametanju socrealističke estetske doktrine, hrvatski arhitekti definiraju modernističku paradigmu "funkcionalnog grada" kao modela za izgradnju nove socijalističke stvarnosti. Nakon što je ranih 1950-ih politička kontrola umjetnosti popustila, lokalne vlasti odmah primjenjuju ideju modernističkog grada kroz pažljivo planiranje infrastrukture. Stoga se odupiranje arhitekata političkim pritiscima države može smatrati sposobnošću arhitekture da se samostalno razvije kada je ograničena od autoritarne vlasti, što je u slučaju Novog Zagreba dovelo do stvaranja drugačijeg grada koji danas pruža dobre uvjete života.

Ključne riječi: Novi Zagreb, modernistički grad, funkcionalni grad, arhitektonska autonomija, otpor arhitekture. 